\section{AN INDICATOR CONCEPT FOR MEASURING THE QUALITY OF LIFE IN KAMPUNG KOTA COMMUNITIES IN THE "SMART CITY"}

\author{
Bagus Nuari Priambudi* \\ Diponegoro University, Faculty of Engineering, Department of Urban \\ and Regional Planning, Prof. Soedarto, SH Street, Tembalang, \\ Semarang and 50275, Indonesia
}

\begin{abstract}
Abstrak. Kampung Kota merupakan suatu cikal bakal perkembangan kota dengan segala aspek penting yang terdapat di dalamnya dengan karakteristik wilayah yang khusus. Keberlangsungan kampung kota dipengaruhi oleh pembangunan fisik yang berada di sekitarnya. Konsep perkembangan Kota Semarang tidak terlepas dari konsep kota cerdas yang sedang trend dalam beberapa tahun belakangan ini. Salah satu aspek yang dinilai suatu kota untuk menjadi suatu Kota Cerdas adalah kualitas hidup. Kajian terhadap QoL (Quality of Life/Kualitas Hidup) sudah semakin banyak dan sangat berkembang dalam beberapa tahun belakangan ini khususnya di kota-kota besar. Namun belum banyak yang mengkaji tentang suatu konsep indikator untuk dapat dijadikan alat ukur kualitas masyarakat kampung kota. Penelitian bertujuan untuk mengkaji konsep indikator sebagai alat ukur kualitas hidup masyarakat. Pendekatan yang digunakan dalam penelitian ini adalah deduktif kuantitatif. Penelitian ini terdiri dari beberapa tahapan yaitu: (1) content validity study, (2) face validity, (3) test reliability dan validitas; (4) analisis dan kesimpulan. Berdasarkan hasil pengumpulan data dan analisis yang sudah dilakukan, terdapat 5 indikator yang dapat dijadikan alat ukur untuk kualitas hidup masyarakat Kampung Kota di Semarang. Indikator dari aspek fisik lingkungan yakni keamanan, kenyamanan lingkungan, dan peran organisasi lokal. Indikator dari aspek sosial ekonomi kesehatan meliputi pendapatan, kesehatan lingkungan dan ketersediaan ruang publik. Kesimpulan studi ini adalah dengan pendekatan yang sudah dilakukan dapat menghasilkan indikator yang cukup sesuai dengan karakteristik masyarakat di lokasi penelitian. Namun masih perlu dilakukan penelitian yang lebih mendalam untuk mengembangkan indikator ini menjadi suatu alat ukur kualitas hidup masyarakat kampung kota di Semarang.
\end{abstract}

Kata kunci: Konsep; Indikator; Kualitas Hidup; Smart City; Semarang

[Title: An Indicator Concept for Measuring the Quality of Life in Kampung Kota Communities in the "Smart city"]. Kampung Kota is the beginning of the city development with all important aspects and has a special regional characteristic. The sustainability of Kampung Kota is affected by physical development around it. The concept of Semarang city development is in line with the concept of smart cities that trending now. One aspect that a city considers being a Smart City is the quality of life. The study of QoL (Quality of Life) has been increasing and has greatly developed in recent years, especially in large cities throughout the country. But it is not yet reviewed for the indicator concept that used as a measure of the quality of life in Kampung Kota communities. In fact, the problems related to the quality of life of the community is so complex. The research aims to study the indicator to measure the quality of life of the community. The method used in this study is quantitative deductive. The study consists of several stages: (1) content validity study, (2) face validity, (3) test reliability and validity; (4) analysis and conclusions. The results show 5 indicators that can be used as a measure of the quality of life of the people of Kampung Kota in Semarang. The indicators of the physic environmental aspects are safety, comfort and the roles of the Neighborhood Association (RT/ RW). The indicators of the socio-economic and health aspects are income, environmental health, and availability of public spaces.

Keyword: Concept; Indicator; Urban Quality of Life; Smart City; Semarang

Citation : Priambudi, B.N. (2019). An Indicator Concept for Measuring The Quality of Life in Kampung Kota Communities in the "Smart city". Jurnal Pengembangan Kota. Vol 7(2): 128-135. DOI: 10.14710/jpk.7.2.128-135 


\section{INTRODUCTION}

Smart cities are a feature of a planned city that is booming in the past of few years and is a concept of urban planning with a sustainable governance that aims to improve the quality of life of the people living in it (Ramadhiani, 2015). This concept is not only to improve the quality of life of its people, but also it strives to integrate the information and communication the technology in daily governance. The main objective is to enhance efficiency, improve public services, and improve people's welfare.

The Minister of National Development Planning revealed several components to assess a city including Smart Cities. These components include economic activities, transportation services, city governance, and effective environmental management (Ramadhiani, 2015). The goal of implementation of smart cities is not only to improve the quality of life for every individual and society that lives in it. But it also creates and raises a sense of comfort, safety, tolerance and continuity in daily activities, so that all aspects of urban planning can be well integrated.

Since 2014 several major cities in Indonesia, those are Jakarta and Surabaya have begun to apply the concept in the development of their cities (Setiaji, 2018). In the process of applying the concept there are several problems such as inadequate supporting infrastructure, readiness of local government, and communities that have not been able to utilize digital technology (Arifwidodo, 2012).

Around 2016, Semarang has implemented the concept. Semarang Smart City combines elements of technology, government and society. The combination of elements is manifested in 6 aspects, that are Smart Governance, Smart Economy, Smart Living, Smart Society, Smart

ISSN 2337-7062 @ 2019

This is an open access article under the CC-BY-NC-ND license (http://creativecommons.org/licenses/by-nc-sa/4.0/). - lihat halaman depan (c) 2019

*Email bagus.nuari14@pwk.undip.ac.id

Accepted 15 October 2019, approved 29 November 2019

This paper is presented in The $2^{\text {nd }}$ International Conference on SMART CITY Innovation (ICSCI) 9 October 2019, Organized by Diponegoro University, Semarang, Indonesia.
Environment. Based on the facts and several previous studies, the application of this concept encountered many very complex problems.

One problem that is often encountered is the lack of land. Nowadays the paradigms of the development of the design Semarang city has changed in line with the emergence of the era of globalization and modernization (Lindarni \& Handayani, 2014; Setiawan, 2010). This causes the aim of the city development changes to be commercially oriented cities (Priambudi \& Haryanto, 2015). This was supported by the statement of Laksana Sunarko, Secretary General of the Indonesian Real Estate DPD (REI) that in Central Java the development of the property business in Semarang City increased significantly since 2010 (Priambudi \& Pigawati, 2014). The effect was the old settlements that located in the center of the city will be eliminated their existences. The lossing of the old settlements (urban villages) that became modern new buildings and commercial-oriented skyscrapers were thought to be the phenomenon of Chopstick Syndrome or "Chopstick Syndrome" (Budihardjo, $1993,2014)$ which is sporadically tall, and slender buildings, toward into the sky, looks like chopsticks. The impact of those the existing of an ancient buildings became dwarfed, even many were displaced or completely disappeared (Priambudi \& Haryanto, 2015). This condition was found in Kampung Petempen, Kembangsari SubDistrict, Semarang City and in the village, there are still local people who remained in their homes located between towering new buildings.

The 6 aspects of Semarang Smart City, has not yet been studied as the indicators to measure the quality of life in accordance with the characteristics of the Semarang City community. It is necessary to do a study about that. Study about the quality of life of the community has been done but more focus only on the health sector. There is still rarely a study of the influence of the organization of urban spatial planning, socioeconomic and environmental quality on people's quality of life (Irfandi \& Irzaidi, 2017). The aim of this study was to review and develop the concept of the indicators to measure the quality of life of the community in accordance with the characteristics of the Kampung Kota in Semarang City. 


\section{METHOD}

The definition of quality of life is an individual perception of its position in life in a cultural context, a value system in which they are located and their relationship to life goals, expectations, standards, and other related ones. There are some problems in the quality of life are very broad and complex including physical health problems, psychological status, level of freedom, social relations and the environment in which they are located (WHO, 2012). Quality of life is a general term to represent how well human needs are met or the extent to which individuals or groups feel satisfied or dissatisfied in various domains of life (Costanza, Fisher, Ali, Beer, Bond, Boumans, Danigelis, Dickinson, Elliott, \& Farley, 2007). Quality of life is considered as one of the most important dimensions to be considered in building a city. The desire to improve the quality of life in certain places or certain people or groups is an important focus that must be given attention to planners. (Lotfi \& Solaimani, 2009). Assessment of quality of life is seen from three distinct aspects there is livability, sustainability and viability (Sariffuddin \& Susanti, 2011). The study approach is a scientific method in the implementation of a study that aims to achieve goals (Prasetyo \& Jannah, 2012). The approach used in this study is quantitative deductive. The purpose of using this method is to development of the concept of measuring the quality of life of the community in accordance with the characteristics of the Kampung Kota community in Semarang. This study consists of several stages, namely: (1) content validity study, (2) face validity, (3) test reliability, and validity; (4) analysis and conclusions. The first stage is content validity, the researcher asks experts to review the suitability of the indicators with the characteristics of the respondents. Basic indicators are the quality of life theory of the WHOQOL BREF, and the research of the Alberta Development Fund (RADF) and the latest research on the same topic. The content validity study was conducted by purposive sampling on two experts in charge of the topic of quality of life. The experts are the researchers from Diponegoro University who have studied quality of life. The second stage is the validity test in the form of a face validation study. The purpose of this implementation is to determine the level of understanding of respondents to the questionnaire given. In this test, the researcher compiled a questionnaire containing the results indicators of content validity which was then given to prospective respondents. Respondents were people who still lived in Kampung Petempen Kembangsari District, Semarang City. The research conducted on July 2019. The number of respondents is based on accidental sampling. Number of sample respondents were 20 people. The third stage is conducting reliability and validity tests (Cronbach alpha and Pearson Product) using SPSS software to determine the validity of the questionnaire that has been done by the respondents. The fourth stage is descriptive analysis and conclusions. In this analysis, the indicators of the validity test results will be reviewed and seen the correlation coefficients used to measure the level of validity of an indicator. The final results determine the level of feasibility of indicators to be used as a measure of the quality of life of urban village communities. The figure 1 shows the mindset of the implementation and location of the research that is explained by the picture below:

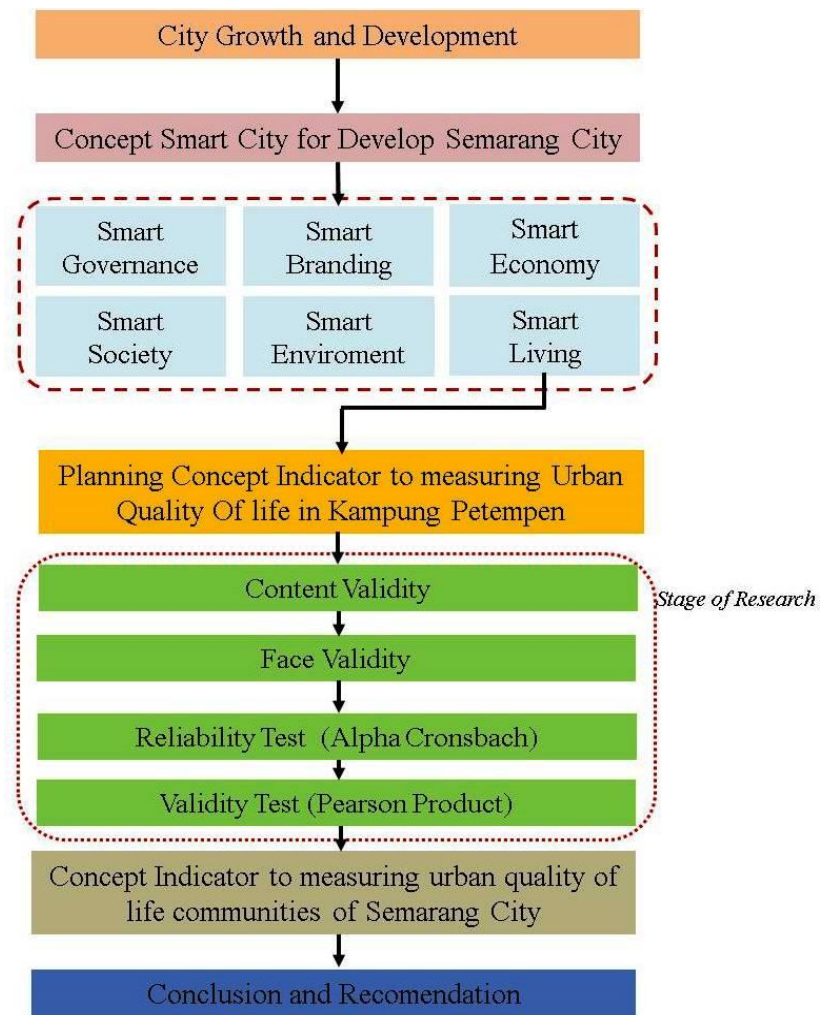

Figure 1. Research Framework 


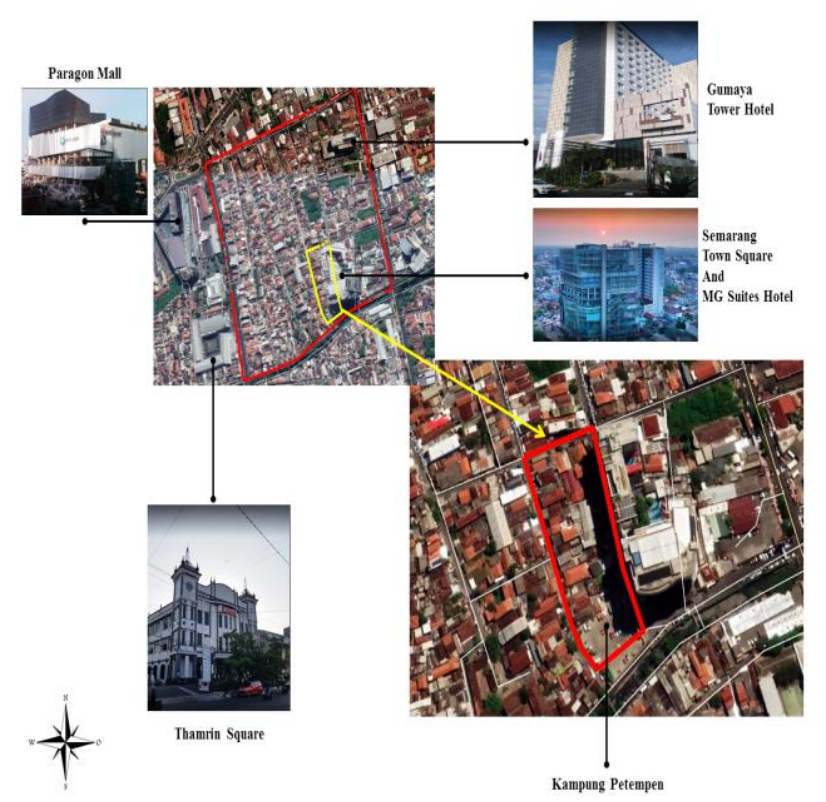

Figure 2. Research Location

\section{RESULT AND DISCUSSION}

The indicators used for planning the quality of life measures for the Kampung Kota communities are explained below (RADF, 2009; Sariffuddin \& Susanti, 2011; WHO, 2012):

Table 1. Concept Indicator in this Research

\begin{tabular}{cl}
\hline No & \multicolumn{1}{c}{ Indicator } \\
\hline Physical and Environment Aspect \\
\hline 1 & Environmental Accessibility \\
2 & Availability of Pedestrian Facilities \\
3 & Ease in Using Public Transportation \\
4 & Environmental Safety and Comfort \\
5 & Environmental Hygiene \\
6 & Safety for activities in this environment \\
7 & calmness of environment \\
8 & Neighborhood Association (RT / RW) \\
9 & Complete Facilities \\
10 & Availability of Green Open Space \\
\hline Social Economic and Health Aspect \\
\hline 1 & Quality of Life Perception \\
2 & Sleep Time and Rest \\
3 & Work Capacity \\
4 & Mind and Concentration \\
5 & Relationships with People Around the \\
6 & Environment \\
7 & Current Environmental Safety and Comfort
\end{tabular}

\begin{tabular}{cl}
\hline No & \multicolumn{1}{c}{ Indicator } \\
\hline & Conditions \\
8 & Current Environmental Safety and Comfort \\
9 & Environmental Health \\
10 & Fun Activities \\
11 & Psychic and Mental Conditions \\
12 & Current Environmental Conditions \\
13 & Work Ability \\
14 & Social relations \\
15 & Chance to get additional income \\
16 & Your Child's Psychic and Mental Conditions \\
17 & Health problems \\
18 & Daily Life \\
19 & Availability of Health Services \\
20 & Availability of Public Space \\
\hline Source: & Whoqol Bref, RDAF, and Researcher Interpretation, \\
2019 &
\end{tabular}

Table 1 shows the 30 indicators used in this study. The indicator was obtained based on WHOQOL BREF, Alberta's Development Fund (RADF), the latest research on the same topic and re-adjusted to the characteristics of urban village communities in Semarang. The indicator was then tested for content validity by two experts in charge of the theme of quality of life. Table 2 shows the results of content validity by two experts of quality of life:

Table 2. Result Indicator Based on Content Validity

\begin{tabular}{|c|c|c|c|}
\hline No & Indicator & Expert 1 & $\begin{array}{c}\text { Exper } \\
2\end{array}$ \\
\hline \multicolumn{4}{|c|}{ Physical and Environment Aspect } \\
\hline 1 & $\begin{array}{l}\text { Environmental } \\
\text { Accessibility }\end{array}$ & Valid & Valid \\
\hline 2 & $\begin{array}{l}\text { Availability of Pedestrian } \\
\text { Facilities }\end{array}$ & Valid & Valid \\
\hline 3 & $\begin{array}{l}\text { Ease in Using Public } \\
\text { Transportation }\end{array}$ & Valid & Valid \\
\hline 4 & $\begin{array}{l}\text { Environmental Safety } \\
\text { and Comfort }\end{array}$ & Valid & Valid \\
\hline 5 & Environmental Hygiene & Valid & Valid \\
\hline 6 & $\begin{array}{l}\text { Safety for activities in } \\
\text { this environment } \\
\text { calmness }\end{array}$ & Valid & Valid \\
\hline 7 & $\begin{array}{l}\text { environment } \\
\text { Neighborhood }\end{array}$ & Valid & Valid \\
\hline 8 & Association (RT / RW) & Valid & Valid \\
\hline 9 & Complete Facilities & Valid & Valid \\
\hline 10 & $\begin{array}{l}\text { Availability of Green } \\
\text { Open Space }\end{array}$ & Valid & Valid \\
\hline
\end{tabular}




\begin{tabular}{|c|c|c|c|}
\hline No & Indicator & Expert 1 & $\begin{array}{c}\text { Expert } \\
2 \\
\end{array}$ \\
\hline \multicolumn{4}{|c|}{ Social Economic and Health Aspect } \\
\hline \multirow{2}{*}{1} & Quality of Life & & \\
\hline & Perception & Valid & Valid \\
\hline \multirow[t]{2}{*}{2} & \multirow{2}{*}{ Sleep Time and Rest } & & Not \\
\hline & & Not Valid & Valid \\
\hline 3 & Work Capacity & Valid & $\begin{array}{l}\text { Not } \\
\text { Valid }\end{array}$ \\
\hline \multirow[t]{2}{*}{4} & Mind and Concentration & Valid & Not \\
\hline & Relationships & & \\
\hline \multirow[t]{2}{*}{5} & People Around the & & \\
\hline & Environment & Valid & Valid \\
\hline \multirow[t]{2}{*}{6} & Income & Valid & Valid \\
\hline & Current Environmental & & \\
\hline \multirow[t]{2}{*}{7} & Safety and Comfort & & \\
\hline & Conditions & Valid & Valid \\
\hline 8 & $\begin{array}{l}\text { Current Environmental } \\
\text { Safety and Comfort }\end{array}$ & Valid & Valid \\
\hline 9 & Environmental Health & Valid & Valid \\
\hline 10 & Fun Activities & Valid & Valid \\
\hline \multirow{2}{*}{11} & Psychic and & & Not \\
\hline & Conditions & Not Valid & Valid \\
\hline \multirow{2}{*}{12} & Current Environmental & & \\
\hline & Conditions & Valid & Valid \\
\hline 13 & Work Ability & Valid & Valid \\
\hline 14 & Social relations & Valid & Valid \\
\hline 15 & $\begin{array}{l}\text { Chance to get additional } \\
\text { income }\end{array}$ & Valid & Valid \\
\hline \multirow{2}{*}{16} & \multirow{2}{*}{$\begin{array}{l}\text { Your Child's Psychic and } \\
\text { Mental Conditions }\end{array}$} & & Not \\
\hline & & Not Valid & Valid \\
\hline 17 & Health problems & Valid & $\begin{array}{l}\text { Not } \\
\text { Valid }\end{array}$ \\
\hline 18 & Daily Life & Valid & Valid \\
\hline 19 & $\begin{array}{l}\text { Availability of Health } \\
\text { Services }\end{array}$ & Valid & Valid \\
\hline 20 & $\begin{array}{l}\text { Availability of } \\
\text { Space }\end{array}$ & Valid & Valid \\
\hline
\end{tabular}

Based on Table 2 there are 24 indicators that are relevant and in accordance with the characteristics of urban village communities in Semarang. The indicator was then compiled into a questionnaire and face validity was carried out to prospective respondents in the research location (Kampung Petempen). Prospective respondents were randomly selected by the researcher and asked to fill out the questionnaire. The next step after face validity is to test reliability and validity with SPSS software. The purpose of conducting reliability tests and validity is to find out the level of suitability of indicators with the characteristics of the community in Kampung Petempen which will be developed into a measurement tool in future studies. Complete results of reliability testing and validity with SPPS software are explained below:

\section{- Result Alpha CronsBach - Reliability}

Table 3. Case Processing Summary Reliability Test Case Processing Summary

\begin{tabular}{|cc|c|c|}
\hline & & $\mathrm{N}$ & $\%$ \\
\hline Cases & Valid & 20 & 100.0 \\
& Excluded $^{\mathrm{a}}$ & 0 & .0 \\
& Total & 20 & 100.0 \\
\hline
\end{tabular}

${ }^{a}$ Listwise deletion based on all variables in the procedure.

Source: Researcher Analysis, 2019

Table 4. Result Alpha Cronsbach Reliability Test Reliability Statistics

\begin{tabular}{|c|c|}
\hline Cronbach's Alpha & N of Items \\
\hline .653 & 24 \\
\hline
\end{tabular}

Source: Researcher Analysis, 2019

\section{- Test Alpha CronsBach - Reliability}

Reliability test aims to determine the level of confidence in the questionnaire that has been made, to be used as a valid data and information collection tool. In the reliability test, all questions and indicators contained in the questionnaire were tested, so that the value of the confidence level of the questionnaire could be determined. The indicator of assessment in the reliability test is the value of Alpha Cronsbach. The basis of the assessment in the reliability test according to (Sujarweni, 2014), namely Alpha Cronbach's value> 0.60 then the questionnaire was declared reliable and consistent. Alpha Cronsbach value $<0.60$ then the questionnaire was declared not reliable and inconsistent.

Table 5. Result Alpha Cronsbach Reliability Test Reliability Statistics

\begin{tabular}{|r|c|}
\hline Cronbach's Alpha & N of Items \\
\hline .653 & 24 \\
\hline
\end{tabular}

Source: Researcher Analysis, 2019 
Based on the results of the reliability test using SPPS software, it was found that Alpha Cronbach's value for the study questionnaire was $0.653>0.60$. Those questionnaires are developed reliably and consistently to be used as data and information collection tools. Furthermore, each indicator/ question in the questionnaire was tested again to determine the level of validity of each indicator. The results of statistical tests for each indicator in the questionnaire showed that for Environmental Aspects there is 1 indicator that is considered invalid and consistent as a measure of the quality of life of urban village communities. The indicator is an indicator of Peace of the Environment. Basically, this indicator cannot indeed be used as a basis or generalized to a condition to assess the quality of life of each individual. Whereas in the socio-economic and health aspects there are 6 indicators that are considered invalid and consistently used as measuring instruments.

These indicators are Relationships with People around the environment, Monthly Finance, Environmental Safety and Comfort, Environmental Health, Availability of Health Services and Availability of Public Spaces. The initial indication of the test results shows that for these 6 indicators it might not be in accordance with the characteristics of the respondents in the Petempen Village. This is based on the score on each indicator given is not large enough and inconsistent. But the hypothesis still needs to be tested for validity to conclude the results.

\section{- Test Pearson Product - Validity}

The next step is the product-moment test (Pearson product). The purpose of this test is to determine the level of suitability of the questionnaire based on data that has been obtained from all respondents. The principle of assessment is carried out in this stage by looking at the correlation between the score and the total score on each indicator according to the results of the respondent's answers. There are two ways to interpret the Pearson product test results. First, by comparing the value of the Pearson correlation with $r$ table. Second, by looking at the Sig value for each indicator (Sujarweni, 2014). The principle was chosen to interpret the results of this test, by comparing the value of the Pearson correlation with $r$ table. Because this method can identify indicators that are suitable and can be developed into a measuring instrument. The level of significance of the indicator with the characteristics of the research location is assumed to be $5 \%$ with the number of respondents $(\mathrm{N})$ as many as 20 so that the $r$-value of the table is 0.444 . Table 6 below shows the comparison of the pearson correlation value with $r$ table for each indicator:

Table 6. Comparation Pearson Corelation with $\mathrm{R}$ Tabel

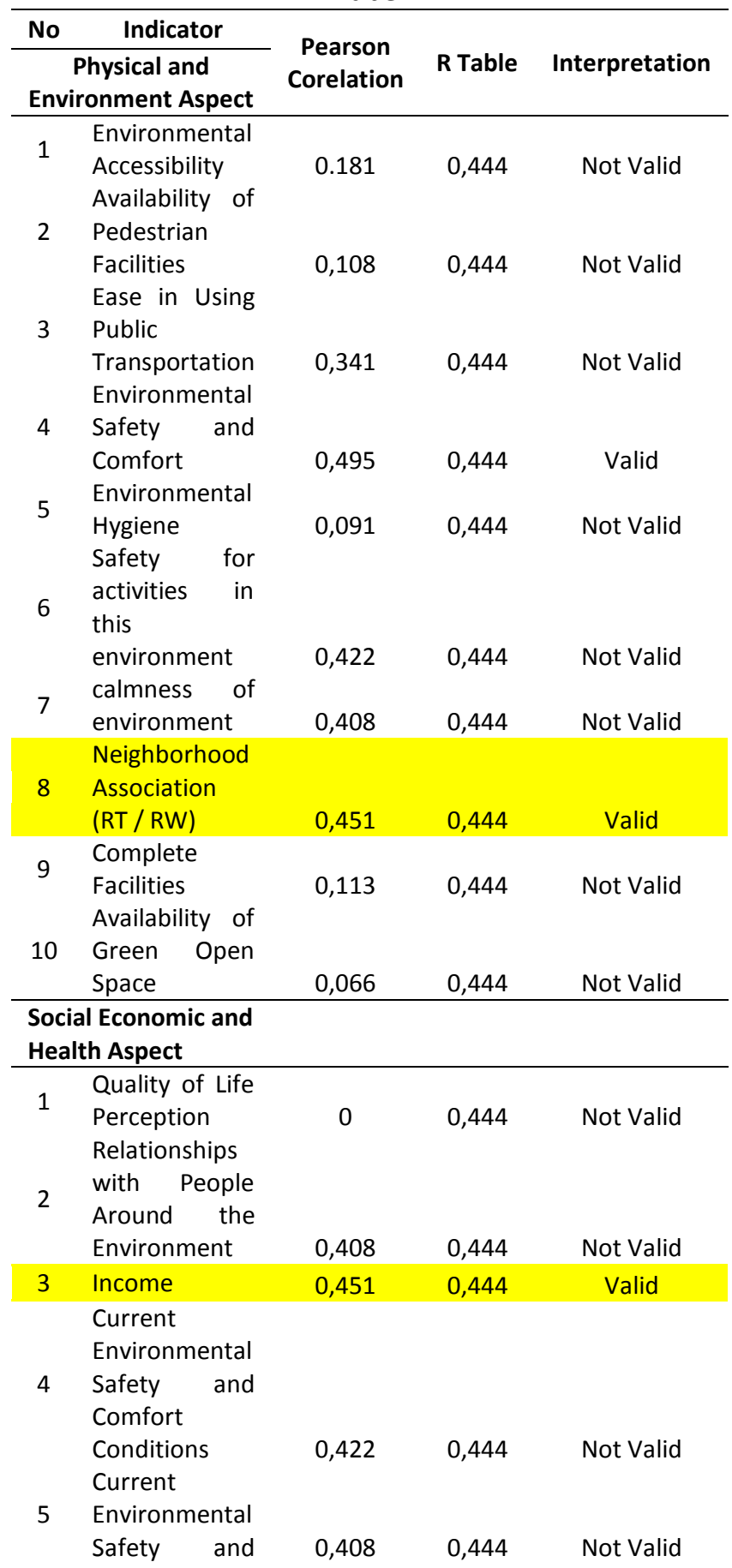




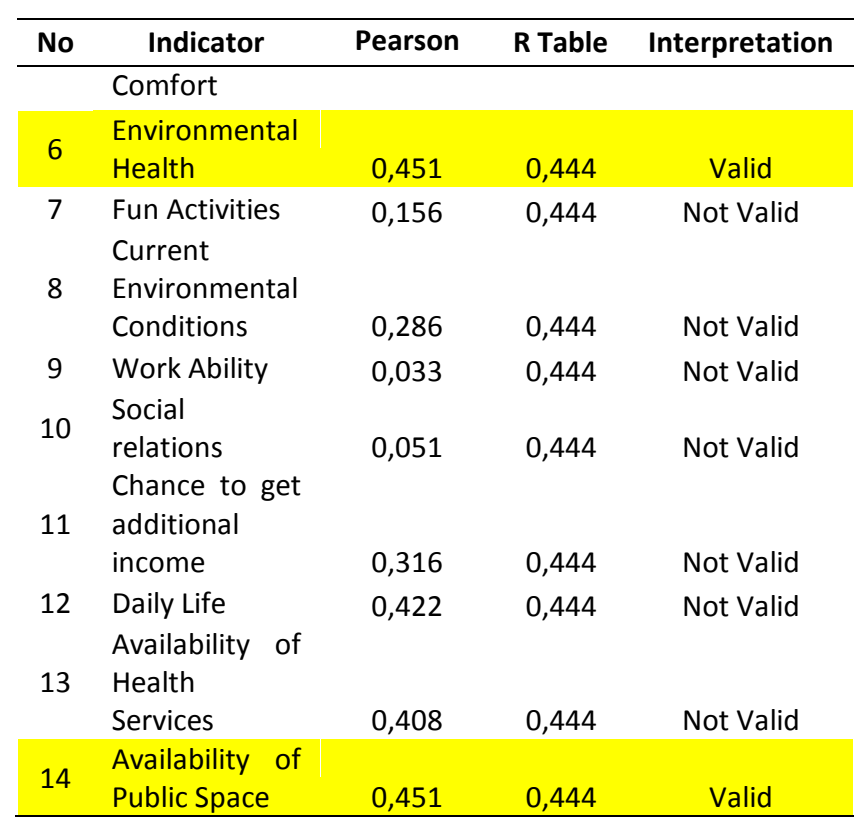

Source: Researcher Analysis, 2019

Based on the results of the validity test by comparing the Pearson product value with $r$ table, it can be seen that there are 5 indicators that are relevant and can be further developed to become a measure of the quality of life of urban village communities in Semarang. Indicators of the physical aspects is environmental safety and comfort, Neighborhood Association (RT / RW). Indicators from the socio-economic aspects of health include Income, Environmental Health, and Availability of Public Spaces.

\section{CONCLUSION}

The concept of Smart City in Semarang needs a lot of development, such as to measure the quality of life of the community. This indicators that can be used as a measure to the quality of life of the people of Kampung Kota in Semarang. Five indicators concept to measure quality of life as follows: environmental safety and comfort, Neighborhood Association (RT / RW), Income, Environmental Health, and Availability of Public Spaces

\section{REFERENCES}

Arifwidodo, S. D. (2012). Exploring The Effect of Compact Development Policy to Urban Quality of Life in Bandung, Indonesia. City, Culture and Society, 3(4), 303-311.
Budihardjo, E. (1993). Kota Berwawasan Lingkungan. Bandung: Alumni.

Budihardjo, E. (2014). Reformasi Perkotaan: Mencegah Wilayah Urban Menjadi'Human Zoo'. Jakarta: Penerbit Buku Kompas.

Costanza, R., Fisher, B., Ali, S., Beer, C., Bond, L., Boumans, R., Danigelis, N. L., Dickinson, J., Elliott, C., \& Farley, J. (2007). Quality of Life: An Approach Integrating Opportunities, Human Needs, and Subjective Well-Being. Ecological economics, 61(2-3), 267-276.

Irfandi, M., \& Irzaidi, K. H. (2017). Pengaruh Kualitas Fisik Ruang Terbuka Publik Aktif Perkotaan Terhadap Kualitas Hidup Masyarakat. Prosiding Temu IImiah IPLBI 2017.

Lindarni, D. A., \& Handayani, W. (2014). Transformasi Kampung Kota di Kawasan Segitiga Emas Kota Semarang. Riptek, 8(11), 2.

Lotfi, S., \& Solaimani, K. (2009). An Assessment of Urban Quality of Life by Using Analytic Hierarchy Process Approach (Case Study: Comparative Study of Quality of Life in The North of Iran). Journal of Social Sciences, 5(2), 123-133.

Prasetyo, B., \& Jannah, L. M. (2012). Metode Penelitian Kuantitatif dan Aplikasi. Jakarta: Rajawali Pers.

Priambudi, B. N., \& Haryanto, R. (2015). Optimalisasi Lahan untuk Pengembangan Rekreasi dan Budaya dengan Metode Highest and Best Use (HBU). Jurnal Pembangunan Wilayah \& Kota, 11(4), 403412.

Priambudi, B. N., \& Pigawati, B. (2014). FaktorFaktor yang Mempengaruhi Perubahan Pemanfaatan Lahan dan Sosial Ekonomi di Sekitar Apartemen Mutiara Garden. Teknik PWK (Perencanaan Wilayah Kota), 3(4), 576-584.

RADF. (2009). Quality of Life and Community Capacity Population Survey: Baseline results: Howard Research and Management Consulting Inc. .

Ramadhiani, A. (2015). "Smart City" Harus Bisa Tingkatkan Kualitas Hidup Warganya, Kompas.com. Retrieved from https://properti.kompas.com/read/2015/0 
3/24/164526921/.Smart.City.Harus.Bisa.Ti ngkatkan.Kualitas. Hidup.Warganya

Sariffuddin, S., \& Susanti, R. (2011). Penilaian Kesejahteraan Masyarakat untuk Mendukung Permukiman Berkelanjutan di Kelurahan Terboyo Wetan, Semarang. Makara, Sosial Humaniora, 15(1), 29-42.

Setiaji, D. (2018). Apa Itu Smart City dan Tantangan Penerapannya di Indonesia. from https://id.techinasia.com/apa-itu-smartcity-dan-penerapan-di-indonesia

Setiawan, B. (2010). Kampung Kota dan Kota Kampung: Potret Tujuh Kampung di Kota Jogja. Pusat Studi Lingkungan Hidup Universitas Gadjah Mada.

Sujarweni, V. W. (2014). SPSS untuk Penelitian. Yogyakarta: Pustaka Baru Press.

WHO. (2012). WHO Quality of Life-BREF (WHOQOL-BREF). Switzerland: World Health Organization. 